\title{
KUALITAS ANC \\ TERHADAP PLASENTA RINGAN
}

\author{
Firdawati H.Palewang $^{{ }^{{ }^{*}}}$, Nurfaini ${ }^{1}$, A.Fahira Nur ${ }^{2}$ \\ ${ }^{1}$ Mahasiswa Kebidanan STIKES Widya Nusantara Palu \\ ${ }^{2}$ Bagian Kebidanan STIKES Widya Nusantara Palu \\ *E-mail : FirdawatiPalewang98@gmail.com
}

\begin{abstract}
ANC adalah pemeriksaan kehamilan sebagai pengawasan sebelum persalinan terutama di tujukan pada pertumbuhan dan perkembangan janin dalam rahim.Pelayanan ANC berkualitas mempunyai kedudukan penting dalam upaya menurunkan angka kematian ibu dan bayi karena melalui pelayanan ANC yang profesional dan berkualitas ibu hamil memperoleh pendidikan tentang cara menjaga diri agar tetap sehat serta meningkatkan kesadaran dan pengetahuan tentang kemungkinan adanya resiko atau terjadinya komplikasi dalam kehamilan, sehingga dapat mencapai kesehatan yang optimal dalam menghadapi persalinan dan nifasnya. Berdasarkan hal tersebut maka perlu diketahui bagaimana kualitas pelayanan ANC yang baik dan berkualitas ${ }^{1}$

Berikut ini penulis akan membahas tentang faktor resiko kualitas ANC terhadap plasenta ringan.

\section{Tinjauan Tentang Plasenta}

Plasenta atau tembuni adalah suatu organ dalam kandungan yang sangat penting untuk menjaga kelangsungan kehamilan karena plasenta berfungsi untuk pertukaran metabolisme dan produk gas antara peredaran darah dari ibu ke janin dan transfer nutrisi dalam pertumbuhan janin. Plasenta normal berbentuk ceper dan bulat, diameter $15-20 \mathrm{~cm}$ dan tebal $11 / 2-3 \mathrm{~cm}$, pada kehamilan cukup bulan, berat plasenta normal 500-600 $\mathrm{gram}^{2}$.
\end{abstract}




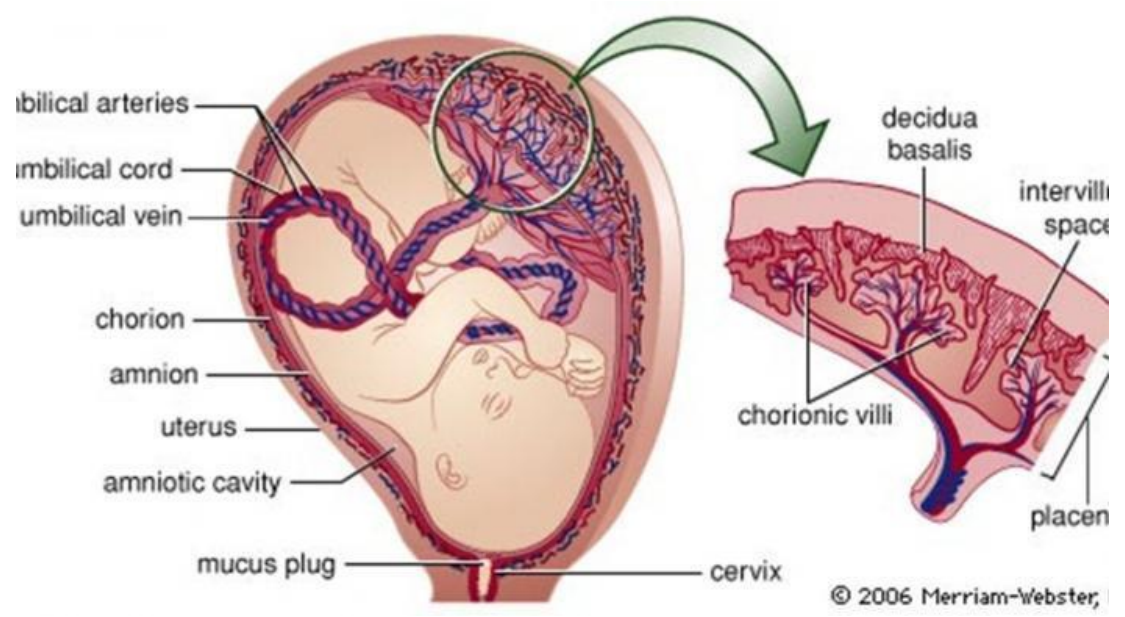

Gambar Pn Plasenta

Fungsi plasenta adalah pertukaran produk-produk metabolisme dan produk gas antara peredaran darah ibu dan janin serta produksi hormon. ${ }^{1,2,3}$

hormon steroid paling penting di produksi plasenta adalah hormon estrogen dan progesteron yang yang konsentrasinya meningkat selama kehamilan. ${ }^{[6\}}$ Plasenta berfungsi untuk nutritif, oksigenasi, ekskresi. Kapasitas pertumbuhan berat janin dipengaruhi oleh pertumbuhan plasenta dan terdapat korelasi kuat antara berat plasenta dengan berat badan lahir. Berat plasenta mencerminkan fungsi dan perkembangan plasenta itu sendiri dan berat plasenta juga dapat memprediksi kemungkinan terjadinya hipertensi dikemudian hari, sebaliknya plasenta ringan dapat mengindikasikan adanya kekurangan asupan nutrisi ke plasenta sehingga terjadi hipoksia plasenta yang pada akhirnya mengganggu fungsinya sehingga dapat berdampak pada bayi dengan Berat Badan Lahir Rendah (BBLR) ${ }^{1,2,3}$.

\section{Tinjauan Tentang Faktor Risiko Berat Plasenta}

Berat plasenta berhubungan dengan beberapa faktor penting dan kelahiran neonatus. Berat plasenta merupakan suatu peringatan yang terkait dengan pertumbuhan plasenta selama kehamilan. Faktorfaktor yang berhubungan dengan berat plasenta yaitu usia, paritas, penyakit, pendapatan, status nutrisi, dan kualitas ANC. 
Kualitas ANC dapat mengakibatkan tidak di ketahuinya tanda bahaya pada kehamilan yang akan mengakibatkan plasenta ringan, persalinan prematur, dan BBLR.

\section{Tinjauan Tentang Resiko kualitas ANC Terhadap Plasenta Ringan}

Plasenta adalah organ yang paling penting antara ibu dan janin selama periode prenatal dan juga bisa terkena resiko terhadap plasenta ringan karena kualitas ANC yang kurang. Ketika kualitas anc kurang pada ibu hamil dapat mengakibatkan tidak di ketahuinya pertumbuhan plasenta yang bisa berdampak pada perkembangan janin pada kehamilan

Untuk mengantisipasi masalah-masalah yang muncul saat kehamilan, semua ibu hamil wajib melakukan Pemeriksaan ANC yang adekuat di fasilitas kesehatan. ANC adalah pemeriksaan kehamilan secara rutin yang bertujuan untuk memeriksa kondisi ibu dan janin, mengawal agar kehamilan dapat berjalan normal dan mempersiapkan persalinan. Pemeriksaan ANC di lakukan sebanyak 4 kali pemeriksaan kehamilan yaitu trimester satu 1 kali pemeriksaan,trimester dua 1 kali pemeriksaan dan trimester tiga 2 kali pemeriksaan Pelayanan ANC yang berkualitas :

1. Memberikan pelayanan dan konseling kesehatan, termasuk gizi, agar kehamilan berlangsung sehat.

2. Melakukan deteksi dini masalah, penyakit, dan penyulit atau komplikasi kehamilan

3. Menyiapkan persalinan yang bersih dan amat.

4. Merencanakan antisipasi dan persiapan dini untuk melakukan rujukan jika terjadi penyulit atau komplikasi.

5. Melakukan penatalaksanaan kasus serta rujukan cepat dan tepat waktu bila diperlukan.

6. Melibatkan ibu dan keluarga terutama suami dalam menjaga kesehatan dan ibu hamil, menyiapkan persalinan da kesiagaan bila terjadi penyulit atau komplikasi. 


\section{Standar pemeriksaan kehamilan 14T}

1. Tinggi Badan dan Berat Badan

2. Tekanan Darah

3. Tinggi fundus uteri

4. TT

5. Tablet FE (minimal 90 Tablet)

6. Tes HB

7. Tes protein urine

8. Tes urine reduksi

9. Tekan pijat payudara

10. Tingkat kebugaran (senam hamil)

11. Tes VDRL (Pemeriksaan Veneral Desease Research Laboratory)

12. Temu wicara

13. Terapi Yodium (Endemic Gondok)

14. Terapi Malaria (Endemic)

Setiap ibu hamil di sarankan untuk melakukan kunjunagan ANC yang komperhensif dan berkualitas minimal 4 kali yaitu 1 kali sebelum bulan ke 4 kehamilan,kemudian 1 kali sekitar bulan ke 6 kehamilan dan 2 kali kunjungan sekitar bulan ke 8 dan 9 kehamilan. 


\section{DAFTAR PUSTAKA}

1. Soetjiningsih. 2014. Tumbuh Kembang Anak. Jakarta: Penerbit Buku Kedokteran EGC

2. Riskesdas. 2013. Badan Penelitian dan Pengembangan Kesehatan, Departemen Kesehatan, Republik Indonesia : Jakarta

3. Plasenta - Wikipedia bahasa Indonesia, ensiklopedia bebas

4. Surinati, I.D.A.K., 2012. Perbedaan Berat Badan Lahir Dan Berat Plasenta Lahr Pada Ibu Hamil Aterm Dengan Anemia Dan Tidak Anemia Di RSUD Wangaya Kota Denpasar Tahun 2011. Universitas Udayana Denpasar.

5. Robert DJ, 2008. Placental Pathology, A Survival Guide. Arch. Pathol. Lab. Med. 2008, 132 (4):641-51.

6. A.Fahira Nur, Adhar Arifuddin, Hermiyanti (2018). Faktor Risiko Plasenta Ringan Pada Ibu Bersalin Di RSU Anutapura Palu. Jurnal Kesehatan Tadulako Vol. 4 No. 1, Januari 2018 : 1-56 http://jurnal.untad.ac.id/jurnal/index.php/HealthyTadulako diakses pada tanggal 12 oktober 2019 